Community: volume 6, nomor 2, Oktober, 2020

p-ISSN: 2477-5746 e-ISSN: 2502-0544

\title{
Motivasi Perempuan Desa Dalam Berwirausaha (Kajian Sosiologi Pembangunan)
}

\author{
Nurlian ${ }^{1}$, Rahmah Husna Yana ${ }^{2}$, Irma Juraida, M.Sos ${ }^{3}$, Triyanto,MA ${ }^{4}$ \\ 1, 2, 3,4 Universitas Teuku Umar \\ Email : nurlian@utu.ac.id,rahmahhusnavana@utu.ac.id,irmajuraida@utu.ac.id, \\ triyanto@utu.ac.id
}

\begin{abstract}
*
The world of entrepreneurship is a world that can be entered by women and men to achieve the desired progress. The absolute and foremost requirement for entering the world of entrepreneurship is high self motivation which is very much needed as the initial foundation in starting and running a predetermined business. Achievement motivation of women in rural areas has led to positive changes in attitude, special behavior in the business world and make women in rural areas have various forms of business. These forms of business are in the industrial sector of home industry, livestock, gardening and convection (sewing). These forms of business emerged because they were adapted to the area of residence of these women and saw business resources that could be developed to be more productive. Motivation that is owned by rural women has helped the family economy and their own needs, has made rural women who have their own businesses make the figure of an independent woman, successful and can help contribute to her family and others. To improve the economy and welfare of rural communities, the local government must pay attention to the businesses that women work in rural areas by providing economic capital, knowledge capital and other business links, so that the businesses they work with become more advanced and successful., because the business built by these women and the role of the government is a socio-economic system that must support one another for economic development.
\end{abstract}

Keywords: Entrepreneurship, Motivation, Women, Rural and Government 
Community: volume 6, nomor 2, Oktober, 2020

p-ISSN: 2477-5746 e-ISSN: 2502-0544

\section{PENDAHULUAN}

Desa adalah suatu wilayah yang berada diluar daerah perkotaan dengan segala keunikannya sendiri dan ciri khasnya sendiri. Desa dalam bahasa Aceh disebut dengan kata "gampong". Masyarakat yang tinggal di daerah pedesaan di sebut masyarakat desa atau masyarakat pedesaan. Masyarakat desa indentik dengan pekerjaan bertani, berkebun, berternak dan berwirausaha lainnya, seperti membuat usaha rumah tangga (home indutri) dalam skala kecil. Home industri dalam skala kecil ni seperti menjahit baju, membuat telur asin, membuat kerajinan kasab emas, minyak goreng dari santan kelapa, makanan-makanan ringan, kue-kue, keripik, buka warung, dan lain-lain. Masyarakat yang terlibat di dalam kegiatan ekonomi home indutri secara umum banyak diperankan oleh kaum perempuan, baik perempuan yang telah menikah ataupun tidak. Peran perempuan desa dalam menjalankan kegiatan ekonomi skala rumah tangga ini didominasi oleh faktor ingin memaksimalkan pendapatan keluarga bagi perempuan yang sudah menikah, sedangkan bagi perempuan yang belum menikah hanya sebagai media untuk mencari uang (mempunyai pendapatan sendiri).

Perempuan desa dan kewirausahaan suatu sistem ekonomi yang saling terikat satu sama lain, dimana perempuan yang tinggal desa memanfaatkan skill atau ketrampilan yang dipunyainya. Pemanfaatan sumber daya tersebut di pengaruhi oleh faktor-faktor kebutuhan keluarga dan faktor kebutuhan untuk diri perempuan itu sendiri. Pemenuhan kebutuhan untuk diri sendiri berlaku untuk perempuan desa yang belum menikah. Kewirausahaan yang dimaksud disini adalah persoalan penting didalam meningkatkan perekonomian suatu bangsa, bahkan suatu individu saja, karena kemajuan dan kemunduran eknomi suatu bangsa sangat tergantung pada sekelompok wirausahaan pada negara-negara berkembang, begitupun di daerah pedesaan, dimana kegiatan wirausahaan yang dilakukan oleh perempuan desaa akan cepat mendongkrak perekonomian masyarakat desa tersebut.

Perkembangan entrepreuner saat ini sangat rendah jika dibandingkan dengan negara-negara maju di Asia. Penyataan ini dapat terlihat pada data jumlah entrepreuner yang ada di Indonesi, dimana kaum usahawaan hanya mencapai 1,56\% dari jumlah penduduk Indonesia. Sedangkan, Mc Clelland berpendapat bahwa, suatu negara akan maju dan makmur apa bila terdapat entrepreuner sedikitnya 2\% dari jumlah penduduk yang ada, seperti yang terjadi pada negara jepang, dimana tercapainya pembangunan ekonomi didukung oleh peran aktif kaum entrepreuner ditingkat sedang dan berwirausaha kecil dari jumlah penduduknya. Selain itu ada beberapa negara-negara maju yanglain yang kemajuannya ekonomi masyarakatnya didukung oleh peran aktif kaum entrepreuner yaitu, Malasyia (5\%) dari jumlah penduduknya, Singapura (7\%) dari

jumlah penduduknya, Amerika (12\%) penduduknya sebagai entrepreuner (Mahesa\&Raharja, 2012).

Gambaran diatas memberikan pertayaan apa yang memicu terbentuknya tindakan usaha nyata pada kaum entrepreuner, termasuk juga pada kaum perempuan 
Community: volume 6, nomor 2, Oktober, 2020

p-ISSN: 2477-5746 e-ISSN: 2502-0544

entrepreuner dalam membangun kehidupan ekonominya, sehingga akan terwujud kehidupan mandiri secara ekonomi serta memberikan dampak kemajuan bagi orang lain. Secara teoritis, modal dari dalam kaum entrepreuner adalah motivasi yang memberi pengaruh langsung terhadap keberhasilan usaha yang dirintisnya. Ada banyak fakta diluar yang berkembang di dalam masyarakat bahwa, adanya modal untuk berusaha tetapi tidak ada motivasi maka usaha tersebut tidak akan berhasil, karena tidak mempunyai tekad, kegigihan, semangat yang kuat. Semangat dan motivasi sebagai modal awal yang hidup dalam diri seseorang entrepreuner untuk merubah hidupnya lebih baik lagi, mencapai standar kemajuan yang diinginkannya, apa lagi fakta diluar didukung oleh banyak pengangguran yang berstatus sarjana tidak mendapatkan pekerjaan dilembaga swasata maupun lembaga pemerintah.

Entrepreunership (kewirausahaan) perempuan pedesaan memiliki dua fungsi yaitu secara makro dan mikro. Fungsi makro mengarah pada adalah entrepreuner sebagai penggerak, pengendali dan pendorong perkembangan bangsa. Sedangkan fungsi mikro entrepreuner sebagai wirausahaan adalah sebagai motivator dan palnnner. Motivator disini adalah sebagai pihak yang menemukan sesuatu dan menciptakan sebuah produk baru, sehingga melahirkan wawasan baru di dalam perkembangan kemajuan ekonomi masyarakat. Sedangkan planner adalah perempuan desa yang berwirausaha sebagai perencana strategi, wawasan dan gambaran korporasi. Sektor ekonomi home industri yang dikendalikan oleh kaum perempuan di pedesaan adalah sebagai cerobong pembagunan desa untuk mendongkrak desa tersebut cepat maju secara ekonomi, tentu saja, hal ini harus didukung oleh pemerintah, selain oleh faktor motivasi dan tekad kuat yang dimiliki oleh perempuan wirausaha di tingkat desa.

Perkembangan wirausahaan yang dilakukan oleh perempuan di daerah pedesaan sudah terjadi dengan berbagai macam persoalan yang dihadapinya. Banyaknya perempuan yang berperan sebagai pengelola bisnis rumah tangga, menimbulkan pertanyaan tentang motivasi yang dimiliki oleh perempuan pengusaha skala kecil. Ada banyak kegiatan usaha ekonomi skala rumah tangga yang dilakukan oleh kaum perempuan di pedesaan dan ada banyak jenis produk kegiatan usaha yang dihasilkan oleh kaum perempuan di pedesaan yang sangat perlu didukung oleh peemerintah secara langung serta prasyarat lainnya yang harus dipunyai oleh kaum perempuan wirausaha di daerah pedesaan. Motivasi apa yang membuat kaum perempuan wirausaha tersebut tetap menjalankan usahanya, walapun hasilnya tidak memadai, hanya bisa membantu perekonomian keluarga misalnya.

\section{TINJAUAN PUSTAKA}

Motivasi adalah modal awal untuk berprestasi dan berjuang untuk mencapai sukses dengan cara berupaya sendiri didalam situasi yang membutuhkan penilaian 
Community: volume 6, nomor 2, Oktober, 2020

p-ISSN: 2477-5746 e-ISSN: 2502-0544

pelaksanaan pekerjaan seseorang dalam kaitannya dengan standar keunggulan. Masyarakat yang mempunyai motivasi tinggi akan menghasilkan pengusaha yang lebih giat, unggul dan berhasil dalam menghasilkan perkembangan ekonomi yang lebih cepat. Pada kelompok usia produktif dan energik, keberhasilan menanamkan etos kerja yang tinggi dan moral kerja yang baik akan menjadikan perempuan sebagai pekerja yang berkualitas, produktif dan handal. Mc Clelland juga menyebutkan bahwa di balik etos kerja tersebut ada motivasi yang memunculkan etos kerja yang tinggi diri seseorang. Semangat atau motivasi untuk berprestasi merupakan prasyarat universal pertumbuhan ekonomi (Ahmadi, 2007).

Motivasi dapat melahirkan pemikiran seseorang untuk hidup lebih maju dan siap untuk berkompetisi, berlomba-lomba dalam melahirkan berbagai hal yang positif, dapat menemukan penemuan-penemuan baru di dalam hidupnya dan usaha yang dirintisnya. Penemuan-penemuan baru tersebut yang berbeda dengan orang lain yang dianggap suatu penemuan baru yang unik dan langka, karena sesuatu yang langka akan dimaknai menarik oleh masyarakat. Pernyataan ini memberi makna bahwa seseorang akan membayar mahal suatu penemuan baru yang langka dan menarik tersebut, sehingga situasi ini merupakan suatu peluang usaha yang harus dikembangkan oleh para entrepreuner ketika memulai usaha dan mengembangkan usaha tersebut (Amri, 2010).

Motivasi adalah suatu perubahan energi didalam diri sendiri seseoramg yang ditandai dengan timbulnya perasaan dan reaksi untuk mencapai tujuan. Motivasi mendorong timbulnya kelakuan dan mempengaruhi kelakuan tersebut serta mengubah kelakuan tersebut menjadi kelakuan bersemangat dalam bekerja/berusaha. Motivasi adalah dorongan dari dalam diri seseorang yang menyadari akan pentingnya kemajuan hidup dan keberhasilannya. Motivasi mampu mengubah kelakuan manusia yang tidak rajin menjadi berkelakuan rajin. Motivasi dapat berfungsi mendorong menimbulkan kelakuan, memotivasi sebagai pengarah dan motivasi berfungsi sebagai penggerak entreupreuner (Darpujiyanto, 2011). Selanjutnya, motivasi merupakan suatu proses yang menyebakan intensitas individu dalam usaha terus menerus mendongkrak usaha tersebut terus mencapai tujuan, artinya, dengan adanya motivasi dalam diri seorang pengusaha akan membuat intensitas usaha tersebut terus bergerak kearah kemajuan dan keberhasilan usaha yang dijalankannya yang mencerminkan interaksi antara sikap, kebutuhan, persepsi dan kepuasan yang terjadi pada diri seseorang yang diakibatkan oleh faktor-faktor dari dalam (instrintik) dan dari luar (ekstrintik). Faktor dari dalam seseorang berupa kepribadian, sikap, pengalaman, pendidikan yang dipunyai oleh seorang entrepreuner dalam mengembangkan usahanya. Sedangkan faktor dari luar adalah berupa pengaruh pimpinan kolega atau faktor diluar dirinya yang sangat komplek yang dapat mempengaruhi dirinya dan usaha yang dijalankannya. Dua faktor tersebut membuat entrepreuner suskes dalam usahanya.

Selanjutnya motivasi dimaknai sebagai daya dorong atau alasan logis seseorang melakukan sesuatu baik seecara motivasi instrinski dan motivasi ekstrinsik. Motivasi 
Community: volume 6, nomor 2, Oktober, 2020

p-ISSN: 2477-5746 e-ISSN: 2502-0544

instrintik di adalah motif-motif yang aktif yang fungsinya tidak perlu dirangsang dari luar individu, akan tetapi suatu semangat yang muncul dari dalam diri individu itu sendiri, sedangkan motivasi ekstrinsik adalah suatu semangat kerja yang muncul karena ada rangsangan dari luar individu (Sardiman, 2009). Selanjutnya, motivasi adalah keinginan yang terdapat pada diri seseorang individu yang mendorongnya untuk melakukan tindakan-tindakan kemajuan untuk usaha yang sedang dijalankannya. Tindakan- tindakan tersebut dilakukan karena di pengaruhi oleh motivasi yang dimiliki, yaitu tindakan-tindakan yang berhubungan dengan kebutuhan pribadi, adanya tujuantujuan dan persepsi orang atau sekelompok orang dan dengan cara apa kebutuhan tersebut dicapai. Winardi menekankan bahwa pada motivasi ini bidikannya adalah motivasi perempuan desa yang mempunyai motivasi dalam melakukan proses berwirausaha yang didorong oleh kedua faktor di atas (Amri, 2010).

Selanjutnya, motivasi diartikan sebagai kekuatan yang ada dalam diri seseorang untuk menggapai keberhasilan dan mencapai tujuan yang telah ditetapkan. Pengertian motivasi ini mengarah pada kekuatan pikiran bawah sadar yang merupakan sugesti energi dasyat yang berperan sebagai pilot dalam diri seseorang individu. Motivasi berwirausaha dapat diartikan sebagai tenaga dorongan yang menyebabkan seseorang melakukan suatu aktivitas wirausaha, selain mendorong munculnya keberanian dalam diri seseorang, sehingga melahirkan minat untuk memulai berwirausaha. Adanya motivasi ini, membuat seseorang individu berpikir kedepan dan berorientasi pada masa depan dan melahirkan tindakan-tindakan positif dalam membangun masa depannya (Agustian, 2011). Pandangan Mc. Cleland, bahwa motivasi berprestasi bermakna sebagai usaha untuk mencapai sukses atau berhasil dalam suatu kompetisi dengan ukuran keunggulan yang dapat berupa prestasi orang lain ataupun dari diri sendiri (Sardiman, 2011).

Kewirausahaan dapat diartikan sebagai proses penciptaan sesuatu yang baru (inovasi baru) yang berbeda dengan yang sudah ada yang bertujuan untuk tercapainya kesejahteraan individu serta nilai tambah bagi masyarakat. Wirausaha mengacu pada orang (pelaku usaha) yang melaksanakan proses penciptaan kesejahteraan, kekayaan dan nilai tambah melalui pengentasan gagasan, memadukan sumber daya dan merealisasikannya menjadi nyata, sehingga wirausaha disebut dengan orang yang mampu menetaskan gagasan menjadi sebuah usaha (Arif dan Nian, 2010). Wirausaha di kaitkan degan motivasi berwirausaha merupakan suatu tingkah laku yang berasal dari dalam diri sendiri yang mengarahkannya untuk mengambil suatu tindakan wirausahaan. Ada beberapa faktor yang menimbulkan motivasi berusaha, adalah sebagai berikut, (1), need for achievement, yaitu motif untuk berkompentisi dengan baik untuk dirinya dan dengan orang lain didalam mencapai prestasi yang tinggi, (2), locus of control, yaitu dimana seseorang memiliki kepercayaan pada diri sendiri maupun orang lain untuk mengontrol usaha yang akan mempengaruhi hasil, (3), independency yaitu dimana 
Community: volume 6, nomor 2, Oktober, 2020

p-ISSN: 2477-5746 e-ISSN: 2502-0544

seseorang pengusaha tidak terikat, memiliki banyak waktu serta bisa bertindak bebas dari tekanan, (4), egoistic passion yaitu sebagai suatu keinginan yang besar, seperti rasa cinta atau semangat ego yang besar untuk urusan pekerjaan, dibandingkan dengan hal lain dalam kehidupannya (Wanto, 2014).

Di dalam dunia usaha, entrepreuner selain mengejar kemajuan ekonomi dengan usaha yang dirintisnya juga mengejar status sosial untuk dipandang sebagai orang suskes sebagai pengusaha oleh masyarakat., karena di tuntut harkat dan martabatnya diakui sebagai entreupreuner merupakan sebuah tantangan nyata bagi pengusaha. Tuntutan ini juga berlaku pada kaum pengusaha perempuan di wilayah pedesaan. Dewasa ini melahirkan pandangan baru bahwa, berkarya itu tidak hanya semata-mata untuk mencari nafkah, melainkan sebagai alat untuk menyatakan harkat dan martabat hidupnya. Pandangan ini melahirkan makna bahwa, membuka lapangan pekerjaan merupakan upaya untuk menghilangkan dan mengurangi ketergantungan pada orang lain memenuhi kebutuhan hidup seseorang tanpa orang lain menerima balas jasa dari yang bersangkutan ( Arif dan Nian, 2010).

Selanjutnya dikatakan bahwa, pembelajaran kewirausahaan diharapkan mampu membangkitkan semangat berwirausaha, berdikari, dan berkarya untuk mengembangkan perekonomian nasional, karena pada dasarnya pembelajaran merupakan salah satu solusi yang sangat berperan dalam mengatasi berbagai masalah sosial-ekonomi yang terjadi di indonesia, misaknya masalah-masalah ketenagakerjaan yang sampai saat ini belum teratasi, dikarenakan angka pengangguran makin meningkat. Untuk mengatasi hal tersebut, belajar berwirausaha sendiri merupakan solusi tepat untuk mengurangi angka pengangguran, sehingga akan terbangun ekonomi kreatif pada masyarakat (Ekawati, 2007).

\section{METODE PENELITIAN}

Metode penelitian yang digunakan dalam penelitian ini adalah penelitian kualitatif deskriptif, yaitu penelitian yang menjelaskan dan menguraikan hasil-hasil penelitian yang ditemukan dengan cara menggambarkan dan menjabarkan dalam bentuk kata-kata/kalimat. Penelitian kualitatif berusaha untuk menjelaskan pemecahan masalah yang ada sekarang berdasarkan data-data, dengan cara menyajikan data dan menganilis dan menginterpretasikannya secara kompratif dan korelatif (Narbuko dan Achmadi, 2004). Sedangkan pengertian penelitian kualitatif selanjutnya adalah sebagai penelitian yang menghasilkan data deskriptif mengenai kata-kata lisan maupun tertulis yang muncul pada tingkah laku yang diamati dari orang-orang yang diamatinya sebagai informan penelitiannya (Moleong, 2010).

Data-data yang digunakan dalam penelitian ini berdasarkan data-data yang ditemukan dilokasi penelitian, yaitu di wilayah pedesaan yang terdapat perempuan yang melakukan kegiatan wirausaha skala rumah tangga, baik disektor pertanian, sektor 
Community: volume 6, nomor 2, Oktober, 2020

p-ISSN: 2477-5746 e-ISSN: 2502-0544

peternakan, sektor perkebunan dan sektor home industri. Sehingga lokasi penelitian ini berada pada desa-desa yang ada kegiatan wirausaha yang dilakukan oleh perempuan, baik usaha yang sudah berjalan lama maupun yang baru dimulai, sehingga data penelitian yang didapatkan sesuai dengan masalah penelitiannya dan sesuai dengan tujuan penelitiannya. Data penelitian yang digunakan dalam penelitian ini adalah data primer (suatu data penelitian yang ditemukan langsung dari lokasi penelitian) baik yang berbentuk wawancara dan lainnya, sedangkan data sekunder pada penelitian ini didapatkan dari berbagai macam bentuk, yaitu dari studi kepustakaan, dokumen, sarana internet, dan lain-lain (Hasan, 2002).

Tehnik pengumpulan data yang dilakukan sesuai dengan langkah dan prosedur penelitian kualitatif, yaitu ditahap awal tetap melakukan observasi, wawancara dan dokumentasi. Observasi diartikan bahwa, suatu proses yang komplek dan tersusun dari proses biologis dan proses pyikologis dan yang diamati adalah gerakan diantara keduanya pada saat yang sama melalui pengamatan dan ingatan (Sugiono, 2011). Sedangkan wawancara dilakukan dengan informan penelitian yang dianggap mampu memberikan informasi/data penelitian yang dibutuhkan, baik disesuaikan pada daftar pertayaan penelitian ataupun tidak membuat panduan wawancaranya. Sedangkan dokumentasi adalah mendokumentasikan semua kegaitan penelitian yang sedang berlangsung, baik foto-foto penelitian dan lainnya.

\section{TEMUAN DAN PEMBAHASAN}

Kegiatan berwirausaha ynag dilakukan oleh kaum perempuan di wilayah pedesaan pada dasarnya bertujuan untuk membantu eknomi keluarga, dikarenakan, secara umum keluarga pelaku usaha home industri ini termasuk dalam katogori keluarga kurang mampu (miskin). Tindakan wirausaha ini dilakukan untuk menambah pendapatan ekonomi yang dilakukan oleh perempuan, khususnya istri atau perempuan yang belum menikah. Usaha home industri ini dibangun karena kondisi keuangan ekonomi tidak mencukupi dalam memenuhi kebutuhan-kebutuhan rumah tangganya, sehingga perempuan berpikir untuk mencari solusi ekonomi sebagai jawaban atas masalah keuangan keluarga yang dihadapi.

Kegiatan wirausaha yang dibangun oleh perempuan di pedesaan tedapat di 3 (tiga) bidang, yaitu, bidang pertanian, bidang perternakan dan usaha rumah tangga dengan menghasilkan berbagai macam jenis produk home indutrinya. Pada usaha ekonomi skala home industri, produk yang dihasilkan seperti, keripik, peyek, pisang sale, kacang asin, telur asin, menjahit kasab sulam benang emas, menjahit baju, dan membuat kue-kue untuk dijual disekolah atau dititipkan di warung-warung kecil. Usaha ini dirintis untuk mendapatkan uang setiap hari atau mengutip (tiga) hari sekali, sehingga perputaran ekonominya berjalan lancar. Sedangkan kegiatan wirausaha di 
Community: volume 6, nomor 2, Oktober, 2020

p-ISSN: 2477-5746 e-ISSN: 2502-0544

sektor pertanian, misalnya menanam tebu, tanaman sayur-mayur, pisang, dan lain-lain. Untuk usaha wirausaha di bidang perternakan misalnya memelihara bebek, ayam kampung, kambing, biri-biri dan sapi. Sedangkan untuk berternak kerbau secara umum di lakukan oleh kaum laki-laki (lebih banyak andilnya suami/anak laki-laki dalam hal ini).

Kegiatan usaha di sektor perternakan, secara umum dilakukan di area belakang rumah. Wilayah perkarangan rumah digunakan untuk membuat kandang ayam, bebek, biri-biri dan kambing, sedangkan untuk kandang sapi dan kerbau berjauhan dengan lokasi rumah, hal ini dikarenakan faktor bau tak sedap dan kondisi kandang yang penuh dengan kotorannya. Bagi perempuan di desa, memelihara sapi, kambing, biri-biri, ayam dan bebek sudah merupakan hal yang bisa dilakukan setiap hari. Pekerjaan ini tidak menimbulkan rasa malu atau gengsi sosial sama sekali, walaupun pekerjaan ini dilakukan oleh perempuan yang masih gadis. Setiap sore perempuan yang belum menikah ini mencari sapi dan kerbau ditempat ternak tersebut merumput dan menggiringnya pulang kekandang untuk dikandangkan dimalam hari. Mengurung sapi dan semua binatang ternak tersebut bertujuan untuk menciptakan kondisi sosial yang aman bagi masyarakat lain, sehingga sapi,kambing dan biri-biri ini tidak mengganggu ketentraman masyarakat serta tidak masuk kedalam perkarangan rumah masyarakat dan merusak tanaman-tanaman yang ada. Perbuatan ini dilakukan atas kesadaran diri sendiri untuk menjaga ketertiban dan kenyaman sosial dalam masyarakat di pedesaan.Wirausaha dibidang perternakan ini tidak mendapatkan penghasilan setiap harinya, akan tetapi mendapatkan penghasilan pada waktu ternak-ternak tersebut sudah cukup umur untuk dijual, sehingga umtuk memenuhi kebutuhan sehari-hari perternak juga melakukan kegiatan lain untuk mencukupi kebutuhan keluarga setiap harinya.

Jenis-jenis usaha home indutri yang dilakukan oleh perempuan di pedesaan seperti yang tergambarkan di bawah ini :

Tabel 4.1: Jenis-Jenis Kegitan Wirausaha Oleh Perempuan Di Pedesaan

\begin{tabular}{|l|l|l|l|}
\hline No & Nama Pelaku Usaha & Jenis wirausaha & \multicolumn{1}{|c|}{ Faktor Motivasi } \\
\hline 1 & Nurhayati & $\begin{array}{l}\text { Memproduksi Peyek } \\
\text { Kacang dan Menjahit Baju }\end{array}$ & $\begin{array}{l}\text { Menambah Keuangan } \\
\text { keluarga }\end{array}$ \\
\hline 2 & Nurlaila & Memproduksi Pisang Sale & $\begin{array}{l}\text { Menambah Keuangan } \\
\text { keluarga }\end{array}$ \\
\hline 3 & Aisyah Abu & Memproduksi Pisang Sale & $\begin{array}{l}\text { Menambah Keuangan } \\
\text { keluarga }\end{array}$ \\
\hline 4 & Nuraini & Meproduksi Pisang Sale & $\begin{array}{l}\text { Menambah Keuangan } \\
\text { keluarga }\end{array}$ \\
\hline 5 & Nurainal & $\begin{array}{l}\text { Memproduksi Peyek } \\
\text { kacang, menjual sirih, } \\
\text { membuat tikar pandan, } \\
\text { menjahit kasab, }\end{array}$ & $\begin{array}{l}\text { Menambah Keuangan } \\
\text { keluarga }\end{array}$ \\
\hline
\end{tabular}


Community: volume 6, nomor 2, Oktober, 2020

p-ISSN: 2477-5746 e-ISSN: 2502-0544

\begin{tabular}{|c|c|c|c|}
\hline & & $\begin{array}{l}\text { memelihara kambing, } \\
\text { ayam dan bebek. }\end{array}$ & \\
\hline 6 & Meliza & Memproduksi Pisang Sale & $\begin{array}{l}\text { Menambah Keuangan } \\
\text { keluarga }\end{array}$ \\
\hline 7 & Cut Herawati & $\begin{array}{l}\text { Memproduksi keripik } \\
\text { pisang, ketela dan ubi }\end{array}$ & $\begin{array}{l}\text { Menambah Keungan } \\
\text { keluarga }\end{array}$ \\
\hline 8 & Eva Marini & Memproduksi Peyek & $\begin{array}{l}\text { Menambah Keunagan } \\
\text { keluarga }\end{array}$ \\
\hline 9 & Yuliati & Memproduksi Peyek & $\begin{array}{l}\text { Menambah Keuangan } \\
\text { keluarga }\end{array}$ \\
\hline 10 & Linda & Memproduksi kacang asin & $\begin{array}{l}\text { Menambah Keuangan } \\
\text { keluarga }\end{array}$ \\
\hline 11 & Eti & Memproduksi kacang asin & $\begin{array}{l}\text { Menambah Keuangan } \\
\text { keluarga }\end{array}$ \\
\hline 12 & Lisa & Memproduksi kacang asin & $\begin{array}{l}\text { Menambah Keuangan } \\
\text { keluarga }\end{array}$ \\
\hline 13 & Sakinah & Memelihara sapi & $\begin{array}{l}\text { Menambah Keuangan } \\
\text { keluarga }\end{array}$ \\
\hline 14 & Anisah & $\begin{array}{l}\text { Memprodkusi pisang sale } \\
\text { dan keripik }\end{array}$ & $\begin{array}{l}\text { Menambah Keuangan } \\
\text { keluarga }\end{array}$ \\
\hline 15 & Marlinda & $\begin{array}{l}\text { Memproduksi telur asin } \\
\text { dan memelihara bebek }\end{array}$ & $\begin{array}{l}\text { Menambah Keuangan } \\
\text { keluarga }\end{array}$ \\
\hline 16 & Siti hajar & $\begin{array}{l}\text { Memelihara kambing dan } \\
\text { ayam }\end{array}$ & $\begin{array}{l}\text { Menambah Keuangan } \\
\text { keluarga }\end{array}$ \\
\hline 17 & Rapasah & $\begin{array}{l}\text { Memelihara kambing, biri- } \\
\text { biri, ayam dan menjual } \\
\text { kelapa tua }\end{array}$ & $\begin{array}{l}\text { Menambah Keuangan } \\
\text { keluarga }\end{array}$ \\
\hline 18 & Salmiah & $\begin{array}{l}\text { Memelihara sapi, kerbau, } \\
\text { dan ayam }\end{array}$ & $\begin{array}{l}\text { Menambah Keuangan } \\
\text { keluarga }\end{array}$ \\
\hline 19 & Nurhayati S & $\begin{array}{l}\text { Menanam Tebu, singkong } \\
\text { dan memelihara ayam }\end{array}$ & $\begin{array}{l}\text { Menambah keuangan } \\
\text { keluarga }\end{array}$ \\
\hline 20 & Nurkhadijah & $\begin{array}{l}\text { Membuka kios kecil- } \\
\text { kecilan, memelihara sapi, } \\
\text { kerbau, dana ayam }\end{array}$ & $\begin{array}{l}\text { Menambah Keuangan } \\
\text { Keluarga. }\end{array}$ \\
\hline
\end{tabular}

Sumber : Hasil Observasi dan Wawancara, 2019

Penjelasan di atas menggambarkan bahwa, kegiatan berwirausaha yang dilakukan oleh perempuan dipedesaan menunjukkan berbagai macam ragam bentuk usahanya. Perbedaan bentuk usaha akan melahirkan perbedaan hasil produksi usahanya. Dari tabel diatas teruraikan bahwa, perempuan pedesaan dan berwirausaha adalah suatu sisi kehidupan yang tidak bisa dipisahkan, dimana perempuan berwirausaha yang tinggal di daerah pedesaan melakukan usaha-usaha ekonomi untuk menambah keuangan 
Community: volume 6, nomor 2, Oktober, 2020

p-ISSN: 2477-5746 e-ISSN: 2502-0544

keluarga. Perbaikan keuangan keluarga ini dilakukan untuk menciptakan kestabilan keuangan keluarga, sehingga rumah tangga tersebut mencapai kriteria sejahtera.

Penentuan bentuk wirausaha yang dilakukan oleh perempuan dipedesaan disesuaikan dengan kondisi alamnya atau kondisi dimana perempuan tersebut tinggal, sehingga bentuk usaha tersebut didalam prosesnya tidak mengalami kendala signifikan, seperti usaha berternak, dimana sumber daya yang dimiliki adalah lokasi usahanya tersedia luas, tersedianya asupan makanan ternak yang terdapat di daerah pedesaan sangat luas. Adaptasi usaha lainnya juga disesuaikan dengan kondisi alam lingkungan dimana pelaku wirausaha tersebut menatap. Kondisi ekonomi keluarga menjadikan salah satu faktor motivasi bagi perempuan dipedesaan untuk bekerja lebih giat dan tekun untuk mendapatkan pemasukan keuangan keluarganya. Faktor yang mempengaruhi motivasi perempuan berwirausaha di daerah pedesaan dikarenakan oleh 2 (dua) faktor, yaitu faktor instrinsik dan faktor ekstrintik. Motivasi adalah suatu peroses psikologis yang mencerminkan interaksi antara sikap, kebutuhan, dan keputusan yang terjadi pada diri seseorang yang diakibatkan oleh faktor-faktor dari dalam [intristik] dan luar dari luar [ekstristik]. Faktor dari dalam seseorang dapat berupa kepribadian,sikap, pengalaman, pendidikan. Sedangkan faktor dari luar seseorang dapat berupa pengaruh lingkungan dimana perempuan tersebut tinggal. Ada beberapa faktor yang menyebabkan munculnya motivasi berwirausaha pada perempuan yang tinggal di pedesaan. Faktor-faktor tersebut seperti di bawah ini:

Tabel 4.2: Faktor-Faktor Motivasi Bagi Perempuan Berwirausaha di Daerah Pedesaan

\begin{tabular}{|l|l|l|}
\hline No. & Faktor Motivasi & \multicolumn{1}{|c|}{ Tujuan bermotivasi } \\
\hline 1 & Faktor Keinginan & Untuk hidup lebih baik dan maju \\
\hline 2 & $\begin{array}{l}\text { Faktor Keinginan } \\
\text { memiliki pendapatan } \\
\text { sendiri }\end{array}$ & $\begin{array}{l}\text { Untuk memiliki uang sendiri dari hasil berusaha sendiri, } \\
\text { keuletan, ketrampilan, kemampuan dan wawasan yang } \\
\text { luas tentang berwirausaha. }\end{array}$ \\
\hline 3 & $\begin{array}{l}\text { Faktor prestis ingin } \\
\text { menjadi pemilik } \\
\text { usaha sendiri }\end{array}$ & $\begin{array}{l}\text { Untuk merasa bangga atas pencapaina yang } \\
\text { didapatkanya sebagai pemilik usaha dan bisa mengakses } \\
\text { pendidikan tinggi bagi anggota keluarganya dan dirinya } \\
\text { (perempuan yang belum menikah). }\end{array}$ \\
\hline 4 & $\begin{array}{l}\text { Faktor keinginan } \\
\text { untuk memberikan } \\
\text { kontribusi }\end{array}$ & $\begin{array}{l}\text { Untuk bisa secara langsung membantu keluarga yang } \\
\text { membutuhkan pertolongan, terjalin relasi yang baik } \\
\text { dalm keluarga, peniuh kasih -sayang, mendukung usaha } \\
\text { yang dilakukan. }\end{array}$ \\
\hline 5 & $\begin{array}{l}\text { Faktor keinginan } \\
\text { untuk memunculkan } \\
\text { ide atau konsep baru }\end{array}$ & $\begin{array}{l}\text { Untuk menciptkan produk-produk baru hasil usahanya, } \\
\text { menciptkan berbagai citra rasa produk yang akan dijual. } \\
\text { Mencari pengetahun baru tentang memajukan usaha dan } \\
\text { mengembangkannya. }\end{array}$ \\
\hline 6 & $\begin{array}{l}\text { Faktor dari } \\
\text { lingkungannya }\end{array}$ & $\begin{array}{l}\text { Memanfaatkan situasi lingkungan untuk proses } \\
\text { kelancaran usahanya. }\end{array}$ \\
\hline
\end{tabular}

Sumber: Analisis Peneliti, 2019 
Community: volume 6, nomor 2, Oktober, 2020

p-ISSN: 2477-5746 e-ISSN: 2502-0544

Faktor keinginan yang dimiliki oleh perempuan yang terjun kedalam dunia usaha skala rumah tangga adalah menunjukkan bahwa, keinginan perempuan untuk berwirausaha dalam sebuah perjuangan untuk mencapai sukses dalam keluarga dengan berupaya sendiri didalam situasi yang membutuhkan penilaian pelaksanaan pekerjaan seseorang dalam kaitannya dengan standar keunggulan. Keinginan tersebut muncul dikarenakan usaha yang digeluti masuk kedalam katagori gampang atau tidak susah, membutuhkan sedikit modal dan dikarenakan oleh kondisi keluarga yang kekurangan pendapatan, memiliki pendapatan sendiri (menjadi perempuan mandiri secara keuangan), merasa bangga dengan pencapaian usaha yang dilakukannya, bisa memberikan kontribusi untuk keluarga, bisa mengembangkan ide-ide atau produkproduk baru usahanya serta memanfaatkan situasi lingkungan dimana perempuan berwirausaha tinggal untuk menjalankan bisnisnya. Keuntungan yang dimilik oleh perempuan yang berwirausaha adalah mendapatkan penghasilan sendiri, membantu ekonomi keluarga, mendapatkan pengalaman baru dan ilmu pengetahuan baru didalam proses berwirausaha. Sedangkan faktor lingkungan (latar belakang kultur) dan pendidikan memengaruhi terbentuknya wirausaha perempuan di pedesaan.

Pendidikan dalam kaitannya dengan perempuan berwirausaha di pedesaan adalah suatu hal yangg diutamakan selain motivasi dari dalam diri seseorang. Pendidikan tinggi akan berdampak pada skala usaha yang digeluti dan berdampak pada perkembangan usaha yang sedang dijalankan. Kendala bagi perempuan sebagai ibu rumah tangga adalah tantangannya membagi waktu untuk melakukan kegiatan usaha dan menyeimbangkan dengan waktu kelurganya, sehingga tidak memunculkan permasalahan dalam keluarga. Adanya motivasi yang tinggi untuk berusaha demi sebuah tercapainya sebuah target usaha yang diinginkan, dimana motivasi yang dimiliki oleh perempuan pedesaan yang terjun kedalam duania usaha adalah suatu dorongan/motivasi dalam melakuan proses usaha, maka dorongan ini disebut dengan motivasi yang muncul dari dalam diri perempuan berwirausaha tersebut (motivasi instrinsik). Bahwa motivasi adalah suatu kekuatan pikiran bawah sadar yang merupakan sugesti, sebuah energi dasyat sebagai pemandu tindakan manusia untuk menciptakan usaha. Motivasi berwirausaha dapat diartikan sebagai tenaga pendorong yang menyebabkan seseorang melakukan aktivitas usaha. Motivasi mampu mendorong seseorang untuk bertindak berani untuk mendirikan usaha sendiri, sehingga dengan adanya motivasi akan membangkitkan minat untuk memulai usaha barunya (Agustian, 2011).

Bahwa benar, seseorang individu yang mempunyai motivasi dari dalam diri, baik laki-laki dan perempuan, itu menjadikan modal utama dalam berwirausaha, selain modal dalam bentuk uang. Motivasi merupakan modal dasar mental untuk merubah cara pandang kaku menjadi mencair tentang hidup sukses melalui jalan usaha yang 
Community: volume 6, nomor 2, Oktober, 2020

p-ISSN: 2477-5746 e-ISSN: 2502-0544

dibangunnya, tanpa adanya motivasi yang tinggi di dalam diri seseorang, maka kehidupannya tidak akan maju, walaupun individu tersebut mempunyai sumber daya nyata yang berlimpah. Motivasi untuk bisa mendapatkan uang sendiri melalui jalur usaha yang dikelola sendiri merupakan suatu hal yang sangat bagus bagi seseorang perempuan didalam menjalani kehidupannya, baik perempuan tersebut telah menikah maupun tidak. Hal ini berujung pada pembentukan perempuan mandiri dan sejahtera secara ekonomi. Motivasi yang dimiliki oleh perempuan pedesaan untuk membuka usaha sendiri melalui usaha home industri merupakan hal yang sudah tepat dilakukan untuk mengurangi permasalahan-permasalahan sosial di dalam masyarakat. Bahwa tanpa adanya motivasi dalam diri seseorang perempuan, maka sosok perempuan tersebut tidak akan maju kehidupannya dan stagnan proses hidupnya, fakta yang terlihat adalah banayak perempuan dipedesaan yang hanya bergantung hidupnya pada suaminya.

Munculnya motivasi bagi perempuan pedesaan dalam berwirausaha dari luar dirinya (ekstrinstik) yaitu uang, penghormatan,tantangan, pujian, kepercayaan, lingkungan, pengakuan,penghargaan, bonus/hadiah dan ucapan terima kasih yang diterima bisa mengarahkan perilaku individu untuk terus mempertahankan usahanya dan mengembangkan usaha tersebut kebentuk yang lebih besar (Shanley F,1997 dalam Santrock, 2007). Perilaku berwirausaha yang muncul karena faktor dari luar dirinya, sangat mendukung proses usaha yang sedang dijalankannya. Berkaitan dengan hal ini, faktor pendidikan juga merupakan salah satu faktor motivasi enstrinsik, dimana pendidikan menemukan proses pembelajaran kewirausahaan yang diharapkan mampu membangkitkan semangat berwirausaha, berdikari, berkarya dan mengembangkan perekonomian nasional, termasuk bisa mengembangkan perekonomian di tingkat daerah, khususnya diwilayah peedesaan.

Faktor keluarga dan tuntutan ekonomi keluarga menjadikan pilihan terakhir bagi perempuan untuk terjun kedalam dunia berwirausaha. Faktor keluarga merupakan faktor penyebab munculnya motivasi esktrinstik bagi perempuan pedesaan untuk mempunyai usaha sendiri. Motivasi ekstrinstik tersebut telah menjadikan dorongan yang kuat terhadap perempuan di pedesaan untuk terus mnegembangkan usahaya. Semangat kerja ini telah membuat perempuan di pedesaan bersikap dan bertindak untuk maju dan bangkit dari kekurangan keuangan keluarga. Motivasi skstrinstik telah membuat perempuan pedesaan berpikir maju kedepan, mencari jalan atau solusi untuk mengatasi permasalahan ekonomi keluarga yang dihadapinya. Motivasi ekstrinsik telah menyebabkan perubahan pola pikir dan perubahan perilaku bagi perempuan dipedesaan mengarah keperilaku berwirausaha. Perilaku ini bertujuan untuk memenuhi kebutuhankebuuhan dirinya sendiri dan kebutuhan keluarga secara mandiri, selain itu pola pikir ini adalah pola pikir yang beriorentasi pada masa depan. Bagi perempuan pedesaan, keadaan hidup dan keadaan keluarga merupakan cermin melihat secara jelas apa yang 
Community: volume 6, nomor 2, Oktober, 2020

p-ISSN: 2477-5746 e-ISSN: 2502-0544

harus dilakukan untuk mengatasi berbagai masalah keuangan dalam keluarganya dan untuk dirinya sendiri.

Penjelasan di atas menggambarkan pengertian bahwa, motivasi yang dimiliki oleh perempuan pedesaan dalam berwirausaha adalah perubahan energi dalam diri pribadi yang ditandai oleh timbulnya perasan dan reaksi dalam diri untuk mencapai tujuan yang diinginkan, sehingga motivasi ini telah mendorong timbulnya bentukbentuk kelakuan baru, yaitu perilaku usaha, mempengaruhinya dan mengubah kelakuan tersebut menjadi kelakuan berwirausaha. Motivasi perempuan pedesaan yang berwirausaha merupakan suatu proses psikologis yang mencerminkan interaksi antara sikap, kebutuhan,persepsi dan keputusan yang terjadi pada diri perempuan tersebut yang diakibatkan oleh motivasi instrinstik dan faktor motvasi ekstrinsik. Pada perempuan pedesaan yang terjun kedalam dunia usaha yang disebabkan oleh dua faktor motivasi tersebut merupakan modal utama nonmateri dalam berwirausaha, dimana modal semanagat tersebut yang harus terus dipelihara, dipertahankan apa bila menghadapi kendala-kendala dalam proses wirausaha tersebut. Apabila perempuan yang berstatus pengusaha skala ekonomi rumah tangga ini dalam bersikap dan berpikir di pandu oleh dua motivasi yang dimilikinya akan melahirkan pandangan dan wawasan yang positif, optimis dan membentuk kemandirian selain membantu menyukseskan proses usaha yang sedang berjalan. Dunia usaha yang dibangun oleh perempuan pedesaan ini bukan mustahil tidak mempunyai kendala di dalam menjalan usahanya, tetap saja usaha-usaha tersebut mempunyai kendala-kendala usaha tersendiri yang harus diatasi dengan objektif dan tepat sasaran oleh perempuan pengusaha tersebut. Kendala yang muncul didalam proses wirausaha tidak menjadikan motivasi instrinstik dalam diri perempuan tersebut menjadi hilang ataupun menurun skalanya, akan tetapi dengan adanya motivasi dari dalam diri, tidak akan mengubah semangat kerja/semangat usaha walaupun sedang menghadapi berbagai kendala atau masalah-masalah dalam proses usahanya. Motivasi instrinsik ini mampu menjadikan benteng pertahanan diri bagi perempuan pedesaan yang terjun kedalam dunia usaha, sehingga usahanya tetap berjalan dengan baik, tetap fokus pada target usaha yang ingin dicapai.

Kendala-kendala berwirausaha yang dihadapi oleh perempuan di pedesaan adalah kendala yang berkaitan dengan keterbatasan modal usaha, pengetahuan dan pengalaman dalam berwiruasaha, serta peran pemerintah setempat untuk membantu meningkatkan perekonomian perempuan diwilayah pedesaan. walaupun demikian, kendala keterbatasan modal usaha tidak menjadikan usaha yang sedang dijalan oleh perempuan pedesaan tersebut menjadi bangkrut atau gulung tikar, bahwa modal dan motivasi berpengaruh didalam keberhasilan usaha, walaupun penyediaan modal bukanlah pengaruh utama didalam berjalannya sebuah usaha, banyak fakta yang terjadi, denga memiliki modal yang minim seseorang mampu memajukan usahanya hingga berkembang sukses, akan tetapi yang sangat diperlukan di dalam proses ini adalah 
Community: volume 6, nomor 2, Oktober, 2020

p-ISSN: 2477-5746 e-ISSN: 2502-0544

semangat kerja, motivasi usaha dan tekad yang kuat sebagai pondasi yang kokoh dalam dunia berwirausaha.

Sedangkan peran pemerintah dalam mengembangkan usaha yang dirintis oleh perempuan di pedesaan, seharusnya memberikan dukungan modal, dukungan pengetahuan melalui pelatihan-pelatihan kreativitas usaha perempuan selain membentuk kelompok-kelompok usaha perempuan dipedasaan. Adanya peran pemerintah daerah dalam hal ini sangat membantu usaha perempuan pedesaan yang sedang berjalan, sehingga kendala-kendala dalam usaha yang dihadapi oleh para perempuan pedesaan tersebut mendapatkan solusinya. Pelatihan-pelatihan usaha yang dirintis oleh perempuan pedesaan tersebut bisa melahirkan berbagai nilai yang positif didalam diri perempuan pengusaha home indutri tersebut serta menjadikan kelompok usaha perempuan ini sebagai kekuatan atau modal pembangunan daerah yang tangguh untuk perbaikan ekonomi masyarakat pedesaan secara khusus. Pemikiran ini dikarenakan kelompok perempuan tersebut adalah kelompok usia produktif dan energik, sehingga sangat perlu ditanamkan etos kerja yang tinggi dan moral yang baik akan menjadikan perempuan berwirausaha di tingkat desa sebagai perempuan yang berkualitas, handal dan produktif di dalam dunia usaha. Semangat kerja atau motivasi berprestasi tersebut merupakan prasyarat universal pertumbuhan ekonomi masyarakat untuk berjuang mencapai sukses dengan cara berupaya sendiri didalam situasi yang membutuhkan kecermatan, penilaian dan melaksanakan kegiatan wirausaha sesuai dengan standar keunggulan yang diinginkan. Pada penjelasan Mc Clelland dalam pembanguan menagatakan bahwa, motivasi untuk beprestasi tinggi akan menghasilkan pengusaha yang lebih giat dan mengahasilkan perkembangan ekonomi yang lebih cepat. Untuk menciptakan kondisi ekonomi maju seperti ini, maka perempuan pedesaan yang terjun kedalam dunia usaha tetap memiliki motivasi tinggi untuk terus bergerak maju dan berambisi hidup sukses, sedangkan di bagian lain, peran pemerintah dibutuhkan untuk membantu menaikkan taraf ekonomi perempuan pedesaan dan membantu memberikan pelatihan-pelatihan yang berkaitan dengan dunia berwirausaha, penilaian diri dan perempuan sukses dan berkualitas, sehingga akan tercapai tujuan pembangunan ekonomi yang diinginkan oleh perempuan itu sendiri dan yang dibangunkan oleh pemerintah setempat.

\section{PENUTUP}

Dunia berwirausaha adalah dunia yang bisa dimasuki oleh perempuan dan lakilaki untuk mencapai kemajuan yang diinginkan. Syarat mutlak dan paling utama untuk memasuki dunia berwirausaha ini adalah motivasi diri yang tinggi yang sangat diperlukan sebagai pondasi awal dalam memulai dan menjalankan usaha yang telah ditetapkan. Motivasi berprestasi yang dimiliki perempuan di pedesaan telah menimbulkan perubahan positif dalam bersikap, bertingkah laku khusus pada dunia 
Community: volume 6, nomor 2, Oktober, 2020

p-ISSN: 2477-5746 e-ISSN: 2502-0544

usaha dan menjadikan perempuan di pedesaan memiliki berbagai macam bentuk usaha. Bentuk-bentuk usaha tersebut berada pada sektor kegiatan ekonomi home indutri, berternak, berkebun dan usaha konveksi (menjahit). Bentuk-bentuk usaha ini muncul karena disesuaikan dengan area tinggal perempuan dipedesaan dan melihat sumber daya usaha yang bisa dikembangkan untuk lebih produktif. Motivasi yang dimiliki oleh perempuan pedesaan ini telah membantu ekonomi kelaurga dan kebutuhan dirinya sendiri, telah membuat perempuan pedesaan yang mempunyai usaha sendiri menjadikan sosok perempuan mandiri, sukses dan bisa membantu memberikan kontribusi bagi keluarganya dan orang lain. Untuk meningkatkan perekonomian dan kesejahteraan hidup masyarakat di pedesaan, maka pemerintah setempat harus memberikan perhatiannya pada usaha-usaha yang digeluti oleh perempuan dipedesaan dengan cara memberikan modal ekonomi, modal pengetahuan serta link bisnis lainnya, sehingga usaha yang digeluti oleh perempuan tersebut menjadi lebih maju dan sukses, karena usaha yang dibangun oleh perempuan tersebut dan peran pemerintah merupakan satu sistem sosial-ekonomi yang harus saling mendukung.

\section{DAFTAR PUSTAKA}

Ahmadi,2007. Pengaruh Pengetahuan Kewirausahaan Dan Motivasi Berprestasi Terhadap Sikap Kewirausahaan. Bandung. Universitas Perpustakaan Indonesia

Amri,Ulil, 2010, Madinah: Motivasi Mahasiswa Aktif di dalam Organisasi. Jakarta: PT. Prestasi Pustaka Karya

Arif,Nian, 2010. Berani Hidup Kaya, jurus itu menjadi Entrepreuner Andal. Yogyakarta ,Pustaka Timur.

Ekawati, 2007, Pengambilan Keputusan Berwirausaha sebagai usaha sampingan. Bandung. Pusaka Setia

Darpujiyanto, 2011. Motivasi Mahasiswa untuk berkarier sebagai wirausaha. Yogyakarta. Pustaka Timur

Sardiman,2009, Interaksi dan motivasi bekerja mengajar. Jakarta. Pt Raja Grafindo Persada.

Moleong, 2007, Metode Peneltian Kualitatif, Bandung, PT Rosda Karya.

Hasan, 2002, Pokok-pokok Materi Metodelogi Penelitian dan Aplikasinya, Jakarta, PT Gralia Indonesia. 
Community: volume 6, nomor 2, Oktober, 2020

p-ISSN: 2477-5746 e-ISSN: 2502-0544

Sugiyono, 2010. Metode Penelitian Kualitatif dan R\&D. Bandung, Alfabeta.

Wanto, 2014. Perencanaan Pembelajaran, Jakarta, Bumi Aksara 